\title{
ПРОФЕСІЙНА ПЕДАГОГІЧНА ДІЯЛЬНІСТЬ МАЙБУТНІХ УЧИТЕЛІВ ЯК ЧИННИК ЇХ ПРОФЕСІЙНОЇ САМОРЕАЛІЗАЦЇ̈
}

\section{Пономарьова Н. О.}

доктор педагогічних наук, професор, декан фізико-математичного факультету, Харківський національний педагогічний університет імені Г. С. Сковороди, м. Харків, Україна

В статті розглянуто вплив професійної педагогічної діяльності майбутніх учителів в період навчання у закладі вищої педагогічної освіти на складні, етапні та динамічні процеси їх професійної самореалізачії, наведено аналіз практичного досвіду вивчення проблеми професійної самореалізаиії майбутніх учителів у ХНПУ імені Г. С. Сковороди.

Ключові слова: професійна самореалізація, педагогічна діяльність, підготовка майбутніх учителів, професійне самовизначення, професійна адаптаиія.

The article considers the influence of professional pedagogical activity of future teachers during the period of study in higher pedagogical education on complex, stage and dynamic processes of their professional selfrealization, the analysis of practical experience of studying the problem of professional self-realization of future teachers in H. S. KhNPU.

Key words: professional self-realization, pedagogical activity, training of future teachers, professional self-determination, professional adaptation.

Впровадження гуманістичної парадигми освіти на шляху до інтеграції України в загальноєвропейський освітній простір характеризується посиленням уваги до успіху кожної людини, врахуванням іiі особливостей та потреб. Тому актуальність проблеми професійної самореалізації фахівців у педагогічній діяльності обумовлена як стратегічними цілями реформування української системи освіти, так і новими пріоритетами сучасного суспільства в цілому — iз розуміннями високої соціальної значущості розвитку і реалізації особистісного потенціалу кожної людини.

Вивчення наукових джерел засвідчує, що поняття професійної самореалізації стало предметом міждисциплінарного аналізу та тісно пов'язане із поняттями «професійний саморозвиток», «професійне самопроєктування», «професійна самоактуалізація», «професійне само- 
удосконалення», «професійна самоосвіта», «професійне самовиховання» та іншими. У психолого-педагогічних розвідках К. АбульхановоїСлавської, В. Андрущенка, Л. Анциферової, Д. Богоявленської, В. Бондаря, О. Дубасенюк, М. Свтуха, І. Зязюна, С. Клімова, Л. Коган, О. Кокуна, Г. Костюка, О. Леонтьєва, І. Манохи, Г. Мілчевської, В. Муляр, І. Підласого, С. Рубінштейна, Г. Рудь, С. Сисоєвої, Л. Сущенко, Т. Титаренко, Н. Чепелєвої та інших розглянуто методологічні засади вивчення професійного саморозвитку особистості. Щодо дослідження сутності, структури та специфіки професійної самореалізації педагогів, то у наукових працях О. Акімової, Р. Гуревича, М. Свтуха, І. Зязюна, В. Кан-Калик, Н. Кузьміної, Л. Мітіної, В. Сластьоніна, Ю. Калугіна, О. Малихіна, І. Наумченко, Л. Рибалко, І. Беха, Ю. Долинської, В. Калошина, Н. Сегеди, Т. Тихонова, П. Харченко, М. Ярославцевої та інших набули розвитку ідеї формування особистості педагогів, їх прагнення до удосконалення, готовності педагогів до самоосвіти і професійного розвитку.

Е. Зеєр пропонує такі етапи професійного становлення особистості: оптація (формування професійних намірів), професійна підготовка, професійна адаптація, первинна та вторинна професіоналізація та професійна майстерність [1]. Щодо професійної самореалізації у педагогічній діяльності, то науковці виокремлюють: початкове професійне становлення педагога, професійну адаптацію (початкову, просунуту, повну адаптованість), безпосередньо самореалізацію педагога [2]. За поглядами вчених, початкове професійне становлення фахівцяпедагога здійснюється під час його навчання у закладі вищої педагогічної освіти, яке завершується формуванням компетентного фахівцяпочатківця, готового розпочати професійну педагогічну діяльність у конкретних умовах закладу освіти, і такий, що має сформованими певні базові фахові компетенції [2]. Професійна адаптація (як пристосування до конкретних умов діяльності) відбувається для фахівців після завершення навчання у закладі вищої педагогічної освіти на робочому місці (або під час зміни місця роботи в подальшому або при зміні виду діяльності тощо) [2].

Разом із тим, зараз чимало здобувачів вищої педагогічної освіти як другого (магістерського), так і першого (бакалаврського) рівня на останніх курсах активно розпочинають професійну педагогічну діяльність у закладах загальної середньої освіти, поєднуючи навчання 
та роботу на посадах учителів-предметників. Зауважимо, що поєднання навчання здобувачів освіти з професійною педагогічною діяльністю у форматі неповного робочого дня та/або тижня відповідає додатковим вимогам до систем внутрішнього і зовнішнього забезпечення якості підготовки та професійного вдосконалення педагогічних працівників [3]. Так, наприклад, на фізико-математичному факультеті ХНПУ імені Г.С.Сковороди з 2011 до 2021 року спостерігається суттєве збільшення відсотка студентів 3-4 курсів бакалавріату та 1-2 курсів магістратури, які працюють у закладах освіти: від 15\% до 45\%. Така тенденція пов'язана, перш за все, із значним попитом на учителів математики, фізики, інформатики в регіоні та в Україні в цілому, і з усіляким заохоченням керівниками закладів середньої освіти зацікавлених студентівмайбутніх учителів до працевлаштування. 3 іншого боку, практика роботи закладів вищої педагогічної освіти засвідчує, що відбуваються певні зрушення і в усвідомленні самими майбутніми учителями значущості та суттєвих переваг набуття власного практичного досвіду педагогічної діяльності ще в період професійної підготовки.

Слід врахувати, що відповідно до діючих вимог, освітні програми підготовки майбутніх учителів в будь-якому разі передбачають їх обов’язкову практичну підготовку - шляхом неперервної педагогічної практики на базі дошкільних, загальноосвітніх, позашкільних, професійних (професійно-технічних) закладів освіти згідно зі спеціальністю та спеціалізацією. Педагогічна практика виконує навчальну, розвивальну, виховну та діагностичну функції у підготовці майбутніх учителів. Водночас, під час такої практики мета, зміст та умови роботи, посадові права та обов'язки майбутніх учителів суттєво відрізняються і не можуть вважатися тотожними до самостійної професійної педагогічної діяльності.

У цьому розрізі потребують додаткового вивчення як теоретичні засади, так й практичний досвід професійної самореалізації студентівмайбутніх педагогів в умовах здійснення ними професійної педагогічної діяльності під час навчання у закладах вищої педагогічної освіти.

Як зазначають науковці, у професійному становлення особистості під час навчання у закладі вищої освіти, визначальну роль відіграють iii власні якості, які розвиваються і вдосконалюються у процесі здобуття професійної освіти, самоосвіти і виховання та, перед усім іiі особиста активність. Залучення до практичної професійної діяльності 
виключним чином стимулює формування особистісної сфери майбутніх учителів. 3 іншого боку, професійна педагогічна діяльність майбутнього учителя сприяє не тільки набуттю ним фахових професійних знань, умінь і навичок, а й якісному засвоєнню способів професійнотворчої діяльності [4]. Під час здійснення власної професійної педагогічної діяльності вже у період навчання у закладах вищої педагогічної освіти майбутні вчителі мають змогу «зсередини» познайомитися 3 організацією роботи закладів освіти, специфікою умов праці, особливостями взаємодії з педагогічним колективом, адміністрацією. Таким чином, етап початкової професійної адаптації прискорюється та сприяє орієнтуванню випускника закладу вищої педагогічної освіти в конкретних умовах педагогічної діяльності та поглибленню його професійного світосприйняття.

У сполученні навчання та професійної педагогічної діяльності студентами-майбутніми учителями завдяки їх тісній співпраці із викладачами закладів вищої педагогічної освіти стимулюється прагнення студентів до наукової діяльності - для пошуку способів розв' язання сформульованих раніше педагогічних задач на основі аналізу різних дидактичних теорій та методичних концепцій [4]. Саме тут закладаються підвалини для прискореної реалізації підетапу просунутої професійної адаптації педагогів і подальшого переходу до повної адаптованості (творчого самовираження).

У 2020-2021 рр. нами було проведено опитування 72-х здобувачів вищої педагогічної освіти другого (магістерського) та першого (бакалаврського) рівнів вищої освіти ХНПУ імені Г.С.Сковороди, які поєднують роботу у закладах загальної середньої освіти із навчанням на денному відділенні за спеціальностями 014 Середня освіта (Фізика), 014 Середня освіта (Інформатика), 014 Середня освіта (Математика), 011 Освітні, педагогічні науки. Серед причин, через які студенти розпочали власну професійну педагогічну діяльність вирізняються прагнення отримати власний практичний досвід (77,4 \%), бажання мати додатковий заробіток (74,2%), запрошення від закладу освіти $(48,4$ \%).

За підсумками опитування до переваг поєднання навчання та практичної роботи у закладах освіти 77,4 \% віднесли можливість свідомого набуття власного практичного досвіду, 66,7 \% — можливість випробувати власні професійні якості для подальшого їх удосконалення. У роботі в закладах загальної середньої освіти 74,2 \% опитуваних 
відчували підтримку з боку педагогічного колективу, а 61,3 \% - 3 боку адміністрації. Водночас, за допомогою у педагогічній діяльності від викладачів закладу вищої педагогічної освіти звернулися тільки 35,5 \% студентів, а підтримки від деканату факультету потребували 41,9 \% опитуваних.

Переважна більшість опитуваних зазначили, що їх основні труднощі під час роботи у закладах освіти були пов'язані із складністю іiі сполучення з навчанням (71\%), хоча тільки 9,1 \% вказали на брак власних навичок самоорганізації, таймменджменту тощо. Заслуговує на увагу те, що тільки 16,1% опитуваних зазначили недостатність знань 3 предмету як фактор наявності труднощів у здійсненні практичної професійної діяльності. Тоді як 28,8 \% відчували недостатність знань 3 методики викладання за фахом, 19,4 \% потребували додаткових загальнопедагогічних та психологічних знань. Складнощі у формуванні відносин із педагогічним колективом та адміністрацією мали 22,6 \% опитуваних.

По завершенню навчання у закладі вищої педагогічної освіти 54,8 \% опитуваних планують продовжити роботу у тому самому закладі середньої освіти, де працювали і саме такий відсоток рекомендує набути такий досвід усім здобувачам вищої педагогічної освіти (рис.1.)

Ви плануєте продовжити роботу у $33 \mathrm{CO}$, де працюєте зараз, після завершення навчання у $3 \mathrm{BO}$ ?

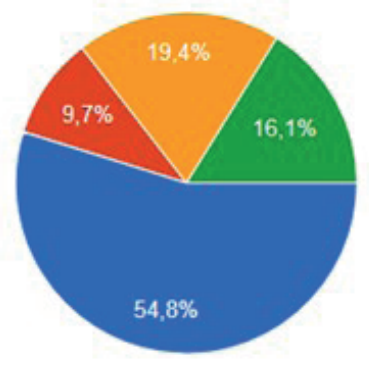

Чи порадили би Ви іншим поєднати навчання в 3 ВО із професійною педагогічною діяльністю у $33 \mathrm{CO}$ ?

Рис.1. Підсумкове опитування здобувачів вищої освіти.

Отже професійна педагогічна діяльність в період навчання у закладі вищої педагогічної освіти має безсумнівний вплив на складний, 
багатоетапний та динамічний процес професійного самовизначення та адаптації майбутніх учителів, що підкріплюється і практичними спостереженнями. Подальшого дослідження потребують теоретичні засади професійної самореалізації педагогічних фахівців з урахуванням нових парадигм побудови системи освіти в Україні та мінливих умовах здійснення професійної педагогічної діяльності.

\section{Список використаних джерел:}

1. Зеер Е. Ф. Психология профессионального образования. Москва : Флинта, 2003. $125 \mathrm{c}$.

2. Абсалямова Я. В. Основні етапи професійної самореалізації викладача вищого навчального закладу. Вісник Національного авіаційного університету. Серія: Педагогіка, Психологія. 2014. № 5. DOI: https://doi. org/10.18372/2411-264X.5.10178

3. Концепція розвитку педагогічної освіти. URL: http://oipopp.ed-sp.net/ public/attached_files/5b7bb2dcc424a809787929.pdf

4. Козирєв М. П., Козловська Ю. Р. Професійне становлення фахівця в умовах вищого навчального закладу. Науковий вісник Львівського державного університету внутрішніх справ. серія психологічна. 2013. Вип. 1. C. 305-313. 